\title{
Effect of L-Prolyl-L-Leucyl-Glycinamide (PLG) on Neuroleptic-Induced Catalepsy and Dopamine/Neuroleptic Receptor Bindings
}

\author{
SIMON CHIU, C. S. PAULOSE AND RAM K. MISHRA ${ }^{1}$ \\ Neuropharmacology Laboratory, Departments of Psychiatry and Neurosciences, \\ McMaster University Medical Centre, Hamilton, Ontario, L8N 3Z5, Canada
}

Received 7 July 1980

\begin{abstract}
CHIU, S., C. S. PAULOSE AND R. K. MISHRA. Effect of L-prolyl-L-leucyl-glycinamide (PLG) on neuroleptic-induced catalepsy and dopamine/neuroleptic receptor bindings. PEPTIDES 2(1) 105-111, 1981. - The mechanism of action subserv-
ing the potential anti-Parkinsonian properties of L-prolyl-L-leucyl-glycinamide (PLG) was investigated in behavioural and alter appreciably the intensity of the cataleptic response Acute administration of PLG (20 and $\left.40 \mathrm{mg} \mathrm{kg}^{-1} \mathrm{SC}\right)$ failed to treatment $\left(20,40\right.$ and $80 \mathrm{mg} \mathrm{kg}^{-1} \mathrm{SC}$ cataleptic response elicited by haloperidol $\left(3 \mathrm{mg} \mathrm{kg}^{-1} \mathrm{IP}\right)$. By contrast, chronic PLG effect of PLG on in vitro dopamine/neuroleptic ror five days) significantly attenuated haloperidol-induced catalepsy. The and spiroperidol was also examined. PLG selectively binding in rat striatum as differentially labelled by apomorphine phine to dopamine receptors in the striatum, but had enhanced the affinity of the specific binding of agonist $\left[{ }^{3} \mathrm{H}\right]$ apomorcal results obtained in the present study raise the possibility on $\left[{ }^{3} \mathrm{H}\right]$ spiroperidol binding. The behavioural and biochemitransmission through interacting with a unique PLG receptor function may facilitate nigro-striatal dopaminergic neurocyclase complex.
\end{abstract}

Haloperidol L-Prolyl-L-leucyl-glycinamide (PLG) Catalepsy Dopamine Parkinsonism

ALTHOUGH it remains to be established whether the tripeptide, L-prolyl-L-leucyl-glycinamide (PLG), as identified by Nair et al. [24] represents the physiologically active hypothalamic factor inhibiting the release of melanocyte stimulating hormone from the pituitary [28], the extraendocrine actions of PLG have recently aroused considerable interest. The potential anti-Parkinsonian properties of PLG have been recognized since it has been demonstrated to be pharmacologically active in potentiating L-DOPA-induced behavioural arousal and antagonizing oxotremorineinduced tremor $[15,25,26]$. Fischer et al. [13] and Barbeau [1] reported encouraging results with PLG in the management of Parkinsonian patients. These considerations strongly suggest that this tripeptide merits serious consideration as an adjunct therapy to L-DOPA in Parkinsonian syndrome.

Accumulating evidence suggests that neuropharmacological profile of activity of PLG may be mediated through interacting with central dopaminergic mechanisms. Friedman et al. [14] reported that PLG increased dopamine synthesis in striatal slices following repeated administration, though this finding could not be confirmed by Kostrzewa et al. [19]. In an attempt to reconcile these apparent discrepancies,
Versteeg et al. [34] injected PLG intracerebroventricularly in rats and found enhanced turnover of dopamine in the caudate nucleus, but not in other brain foci. In accord with these neurochemical findings, it has been further shown that PLG, when administered alone or in combination with amphetamine, elicited rotational behaviour in a direction suggestive of its alleged dopamine-releasing influence on pre-synaptic dopaminergic terminals $[30,32]$. In contrast to prototypal dopamine agonists and antagonists, PLG failed to compete for specific neuroleptic receptor binding in the striatum in vitro [11] or to modify the levels of striatal cAMP [8]. On the other hand, Mishra and Makman [21] found that PLG inhibited dopamine-sensitive adenylate cyclase activity in monkey and rat striatum in a dose-related manner.

In view of possible parallelism between the cataleptogenic properties of antipsychotics and their liabilities of inducing extrapyramidal motor dysfunction in humans $[3,16]$ we have used haloperidol-induced as the behavioural assay to study the interactions of PLG with dopaminergic mechanisms in the extrapyramidal systems. The influence of PLG on in vitro dopamine/neuroleptic receptor binding as differentially labelled by $\left[{ }^{3} \mathrm{H}\right]$ apomorphine and $\left[{ }^{3} \mathrm{H}\right]$ spiroperidol in the striatum was also investigated. 
METHOD

\section{Subjects and Drugs}

Male Sprague-Dawley rats purchased from the Canadian Breeding Farm, Quebec, were used throughout the studies. The animals weighing between $200-250 \mathrm{~g}$ upon arrival were housed individually in plastic cages in temperaturecontrolled rooms maintained on a 12-12 light-darkness cycle. They were allowed free access to food (Purina rat chow) and water to acclimatize themselves for at least three days prior to use in experiments.

The sources of the drugs used were as follows: haloperidol, McNeil Laboratories, Canada; spiroperidol, Janssen Pharmaceutica, Belgium; ADTN (2-amino-6,7-dihydroxy1,2,3,4-tetrahydronaphthalene), Burroughs Wellcome, U.K.; dopamine (APO), TRH (Thyrotropin releasing factor: Proglu-His-Pro- $\mathrm{NH}_{2}$ ) and PLG from Sigma Chem. Co. USA and the analogue of Met-enkephalin (DALA: (Tyr-Ala-GlyPhe-Met- $\mathrm{NH}_{2}$ ) from Calbiochem, USA; [1-Phenyl-4- ${ }^{3} \mathrm{H}$ ] spiroperidol $(25.64 \mathrm{Ci} / \mathrm{mmole})$ and $\left[8,9-{ }^{3} \mathrm{H}\right]$ apomorphine $(38.6$ $\mathrm{Ci} / \mathrm{mmole}$ ) were purchased from New England Nuclear, Boston, USA. All other chemicals used were of the finest reagent grade available.

\section{Catalepsy Testing}

At each experimental session the rats were transferred to a sound-attenuated room and allowed to habituate to the environment for at least half-an-hour prior to drug treatments. Catalepsy was assessed by the simple bar test as described previously by Chiu and Mishra [6]: it entailed gently placing both front paws of the rats in extended positions on a horizontal metal bar mounted $10 \mathrm{~cm}$ above a wooden platform and measuring the time spent in maintaining this abnormal motor state. The animals were tested three times at each specified time interval after drug administration and the maximal intensity of the cataleptic response was recorded in seconds.

For the series of acute experiments, naive rats were injected with PLG ( 20 and $40 \mathrm{mg} \mathrm{kg}^{-1} \mathrm{SC}$ ) ten seconds prior to haloperidol ( $3 \mathrm{mg} \mathrm{kg}-1$-IP) while the haloperidol-control animals received haloperidol $\left(3 \mathrm{mg} \mathrm{kg}^{-1}\right.$ IP) in addition to $0.9 \%$ saline solution. Haloperidol was dissolved in $0.1 \mathrm{M}$ tartaric acid prepared in $0.9 \%$ saline solution and PLG was dissolved in $0.9 \%$ saline solution immediately prior to use. All rats received drug treatments only once.

For the series of chronic experiments, rats were randomly assigned to four groups and groups I-III received PLG at the doses of 20,40 and $80 \mathrm{mg} \mathrm{kg}^{-1} \mathrm{SC}$ respectively twice daily for five days. Group IV received isotonic saline $(1.0 \mathrm{ml} \mathrm{SC})$ for the same period of time. All rats were challenged with haloperidol $\left(3 \mathrm{mg} \mathrm{kg}^{-1} \mathrm{IP}\right)$ ten seconds after the last drug treatment. Catalepsy was evaluated every $30 \mathrm{~min}$ for the first hour and every hour thereafter, for a total of four hours. All injections were carried out at 9 am and 5 pm daily to prevent interference with their circadian rhythm.

\section{$\left[{ }^{3} \mathrm{H}\right]$ Apomorphine Binding Assay}

The binding assay for $\left[{ }^{3} \mathrm{H}\right]$ apomorphine was carried out essentially as described by Creese et al. [10] with minor modifications. The freshly dissected striatum was initially suspended in 50 volumes of $50 \mathrm{mM}$ Tris-HCL buffer ( $\mathrm{pH} 7.7$, at $25^{\circ} \mathrm{C}$ ) and homogenized with Polytron homogenizer (set- ting at 6) for 20 seconds. The tissue homogenate was twice centrifuged at $40,000 \times \mathrm{G}$ for $10 \mathrm{~min}$ in refrigerated Sorvall centrifuge after resuspending in fresh Tris buffer. The final pellet was suspended in $50 \mathrm{mM}$ Tris buffer consisting of $0.1 \%$ ascorbic acid, $120 \mathrm{mM} \mathrm{NaCl}, 5 \mathrm{mM} \mathrm{KCl}, 2 \mathrm{mM}$ $\mathrm{CaCl}_{2}$ and $10 \mu \mathrm{M}$ pargyline $\left(\mathrm{pH} 7.1\right.$ at $25^{\circ} \mathrm{C}$ ) at the approximate concentration of $20 \mathrm{mg}$ of wet tissue weight per $\mathrm{ml}$ of incubation buffer. The standard assay consisted of 0.4 to 0.6 $\mathrm{mg}$ protein of the brain homogenate, $3.0 \mathrm{nM}$ of $\left[{ }^{3} \mathrm{H}\right]$ apomorphine and the buffer with or without various concentrations of the competing ligands or drugs in a total incubation volume of $0.6 \mathrm{ml}$. Incubation was carried out in triplicate in a water shaker bath maintained at $37^{\circ} \mathrm{C}$. Upon termination of the $10 \mathrm{~min}$ incubation period, the contents of the incubation tubes were rapidly filtered under partial vacuum over Whatman GF/B filters, followed by four $2.2 \mathrm{ml}$ washes of ice-cold $50 \mathrm{mM}$ Tris- $\mathrm{HCl}(\mathrm{pH} 7.1)$. The filters were then placed in liquid scintillation counting vials containing $10 \mathrm{ml}$ of PCS counting cocktail (Amersham Corporation, Chicago, Illinois, USA) and after equilibration for at least six hours, were counted in liquid scintillation counter.

The specific binding of $\left[{ }^{3} \mathrm{H}\right]$ apomorphine was defined as the difference in binding occurring in the absence and in the presence of $10 \mu \mathrm{M}$ of unlabelled apomorphine. For drug displacement studies, increasing concentrations of each drug were added to the incubation tubes containing $3 \mathrm{nM}\left[{ }^{3} \mathrm{H}\right]$ apomorphine and the drug concentration required to inhibit $50 \%$ of the specific binding of the radioligand ( $\mathrm{IC}_{50}$ value) was calculated by $\log$ probit analysis. Protein determination was performed according to the method of Lowry et al. [20].

\section{$\left[{ }^{3} \mathrm{H}\right]$ Spiroperidol Binding Assay}

The procedure for $\left[{ }^{3} \mathrm{H}\right]$ spiroperidol binding was identical to that of $\left[{ }^{3} \mathrm{H}\right]$ apomorphine except that the incubation was carried out for $15 \mathrm{~min}$. The specific binding of $\left[{ }^{3} \mathrm{H}\right] \mathrm{spi}-$ roperidol was defined as the difference between the total binding and the non-specific binding in the presence of 500 $\mathrm{nM}$ of unlabelled spiroperidol. The blank value of nonspecific binding in the presence of $1 \mu \mathrm{M}$ of $(+)$-butaclamol was similar to that obtained with $500 \mathrm{nM}$ of unlabelled spiroperidol. For drug displacement studies, increasing concentrations of each drug were added to the series of incubation tubes containing $0.25 \mathrm{nM}$ of $\left[{ }^{3} \mathrm{H}\right]$ spiroperidol. The $\mathrm{IC}_{50}$ values of competing drugs were calculated by log probit analysis.

\section{Statistics}

The behavioural data were subjected to ANOVA for multiple testing. The biochemical data were analyzed by Student's $t$-test.

\section{RESULTS}

\section{Behavioural Studies}

As depicted in Fig. 1 acute administration of haloperidol ( $3 \mathrm{mg} \mathrm{kg}^{-1}$ IP) elicited maximal cataleptic response at two hours, but the duration of the drug effect extended beyond the 4-hour observation period. Pre-treatment with PLG at the respective doses of 20 and $40 \mathrm{mg} \mathrm{kg}^{-1} \mathrm{SC}$ did not significantly attenuate haloperidol-induced catalepsy at all the time intervals. PLG when administered alone, either acutely or chronically did not produce anv 


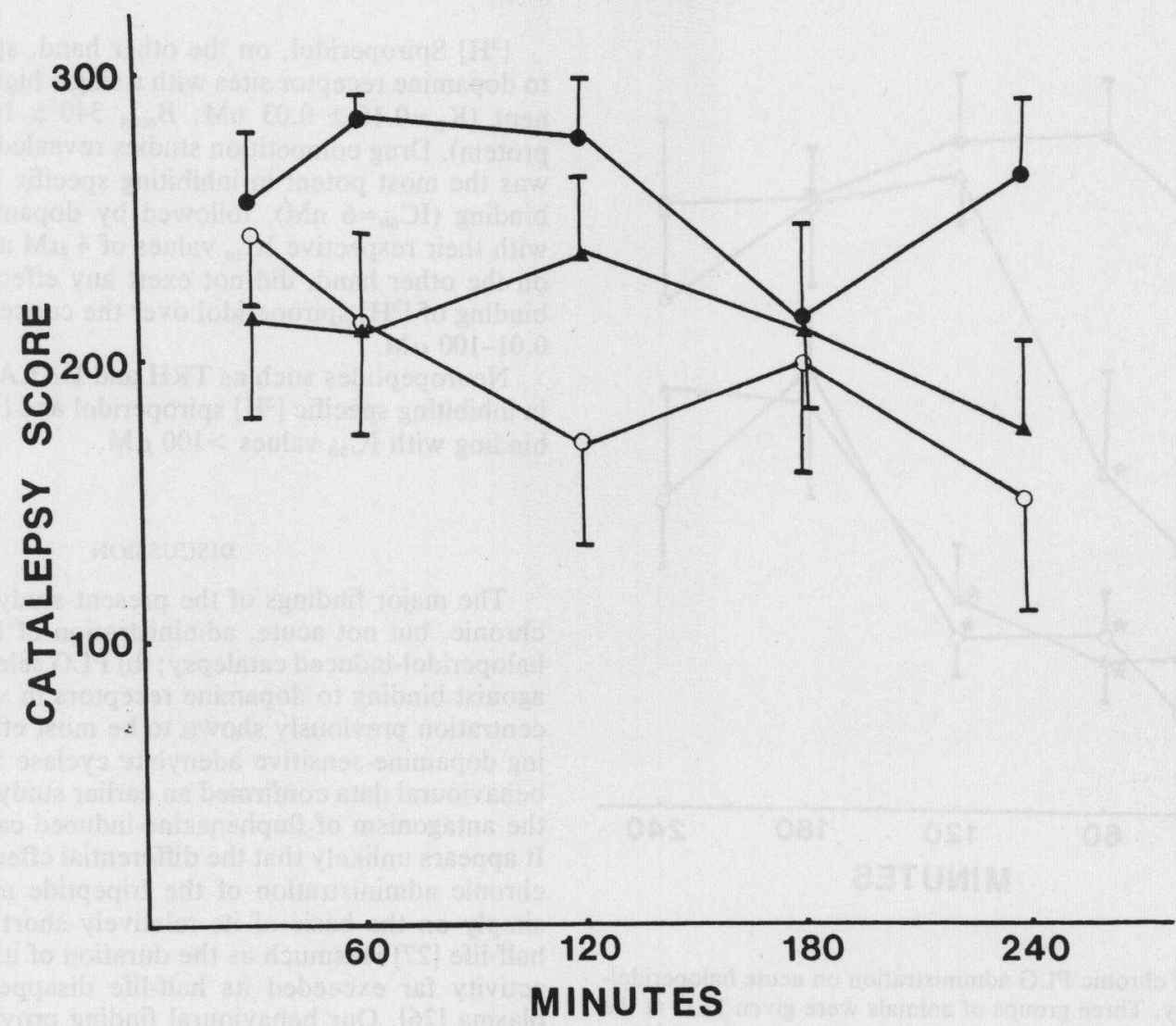

FIG. 1. Effect of acute PLG treatment on haloperidol-induced catalepsy. Two groups of rats $(n=6)$ were pretreated with PLG at the doses of $20 \mathrm{mg} \mathrm{kg}^{-1} \mathrm{SC}(\Delta)$ and $40 \mathrm{mg} \mathrm{kg}^{-1}(0)$ respectively, followed ten seconds later by haloperidol ( $\left.3 \mathrm{mg} \mathrm{kg}^{-1} \mathrm{IP}\right)$. Haloperidol-control group $(\mathbf{n}=8)$ received equivalent volumes of isotonic saline followed ten seconds later by haloperidol ( $\left.3 \mathrm{mg} \mathrm{kg}^{-1} \mathrm{IP}\right)$. Catalepsy and statistical analysis of results were conducted as previously described in Method.

havioural events such as hyperactivity, sedation or catalepsy (data not shown).

For the chronic series of experiments, whereas protracted treatment with isotonic saline did not alter the intensity of haloperidol-induced catalepsy, rats which were chronically administered with PLG at the doses of 20,40 and $80 \mathrm{mg}$ $\mathrm{kg}^{-1} \mathrm{SC}$ twice daily for five days developed significant behavioural tolerance towards acute haloperidol-induced catalepsy (Fig. 2). The anticataleptic action of PLG was evident at 30,60 and $120 \mathrm{~min}$ after haloperidol challenge in the 40 and $80 \mathrm{mg} \mathrm{kg}^{-1}$ PLG-groups while in the $20 \mathrm{mg} \mathrm{kg}^{-1}$ PLG Group PLG-group antagonism of haloperidol catalepsy was observed for the first hour after injection.

\section{Dopamine Receptor Binding Studies}

Scatchard analysis of $\left[{ }^{3} \mathrm{H}\right]$ apomorphine specific binding to dopamine receptors in the striatum indicated the existence of a single high-affinity binding site characterized by a dissociation constant $\left(\mathrm{K}_{\mathrm{D}}\right)$ of $4.44 \pm 0.14 \mathrm{nM}$ and a maximal number of binding sites $\left(B_{\max }\right)$ of $269 \pm 5.34{\text { fmoles } \mathrm{mg}^{-1}}^{-1}$ protein (Table 1). Analysis of the displacement curves for various drugs indicated that spiroperidol competed for specific $\left[{ }^{3} \mathrm{H}\right]$ apomorphine binding in a biphasic mode, with $\mathrm{IC}_{50}$ values of $104 \mathrm{nM}$ and $2 \mu \mathrm{M}$. Dopamine and ADTN were less
TABLE 1

EFFECT OF PLG ON SPECIFIC $\left[{ }^{3} \mathrm{H}\right]$ APOMORPHINE BINDING IN RAT STRIATUM IN VITRO

\begin{tabular}{lcc}
\hline Rat Striatum & $\begin{array}{c}\text { Specific }\left[{ }^{3} \mathrm{H}\right] \text { apomorphine binding* } \\
\mathbf{B}_{\text {max }}\end{array}$ & $\begin{array}{c}\mathrm{K}_{\mathrm{D}} \\
(\mathrm{nM})\end{array}$ \\
\hline (fmoles $\mathrm{mg}^{-1}$ protein) & $269.0 \pm 5.34$ & $4.44 \pm 0.14$ \\
Control (No PLG added) & $278.5 \pm 1.19$ & $2.26 \pm 0.2$ \\
\hline$\mu \mathrm{M}$ PLG added $\dagger$ & & \\
\hline
\end{tabular}

*Specific binding on $\left[{ }^{3} \mathrm{H}\right]$ apomorphine was defined as the binding displaceable by $10 \mu \mathrm{M}$ of unlabelled apomorphine. Receptor binding parameters $\left(B_{\max }\right.$ and $K_{D}$ ) were determined by the Scatchard analysis method. The values represent the mean \pm SEM from five independent experiments with triplicate determinations.

+PLG at the final concentration of $1 \mu \mathrm{M}$ was added to the reaction mixture prior to incubation.

$\ddagger$ Significantly different from control, $p<0.05$. 


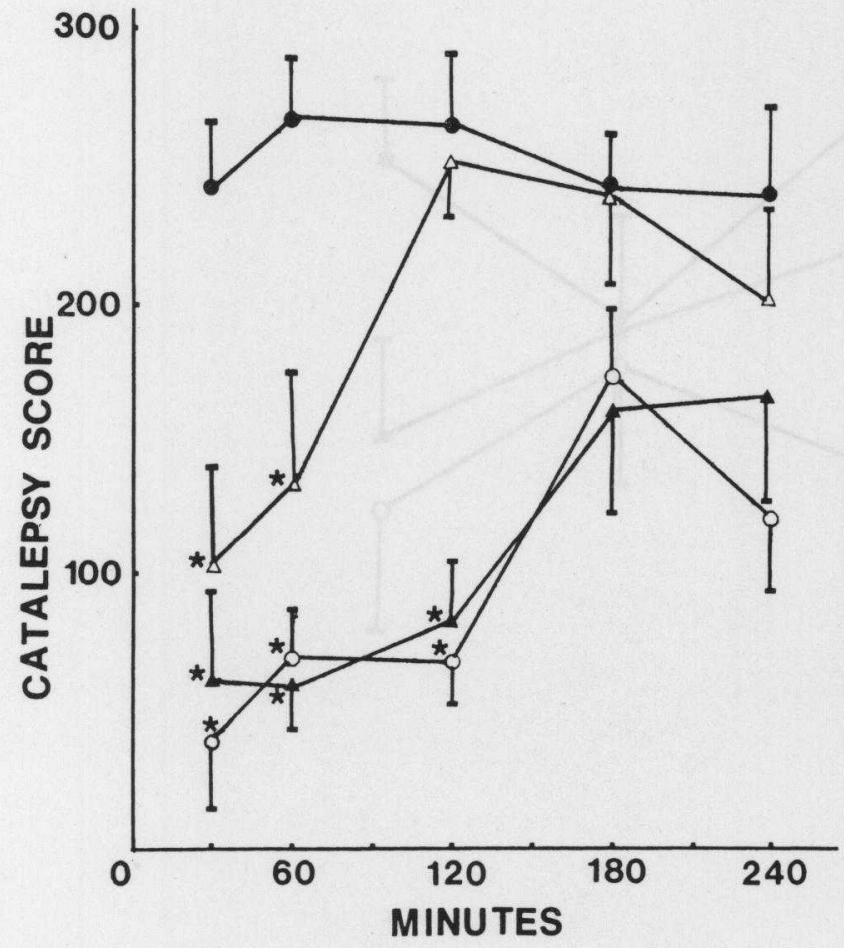

FIG. 2. Effect of chronic PLG administration on acute haloperidolinduced catalepsy. Three groups of animals were given PLG at the doses of $20 \mathrm{mg} \mathrm{kg}^{-1} \mathrm{SC}(\triangle ; \mathrm{n}=6), 40 \mathrm{mg} \mathrm{kg}^{-1} \mathrm{SC}(\Delta ; \mathrm{n}=6)$ and $80 \mathrm{mg}$ $\mathrm{kg}^{-1} \mathrm{SC}(O ; \mathrm{n}=6)$ respectively twice daily for five days and challenged with haloperidol ( $3 \mathrm{mgkg}^{-1}$ IP) ten seconds after the last PLG treatment. Haloperidol-control group $(\bullet ; n=8)$ received $0.9 \%$ saline solution $(1 \mathrm{ml} \mathrm{SC})$ for the same period of time and haloperidol was injected ten seconds after the last saline treatment. Catalepsy testing and statistical analysis of results were carried out as described in Method. ${ }^{*} p<0.01$ : significantly different from the haloperidolcontrol at the respective time interval.

potent than spiroperidol in competing for $\left[{ }^{3} \mathrm{H}\right]$ apomorphine, with their respective $\mathrm{IC}_{50}$ values of $190 \mathrm{nM}$ and $570 \mathrm{nM}$. These values agree essentially with those reported by Creese et al. [9]. The non-specific binding in the presence of $10 \mu \mathrm{M}$ of unlabelled dopamine is similar to that obtained with $10 \mu \mathrm{M}$ of unlabelled apomorphine.

In contrast, PLG did not compete for specific $\left[{ }^{3} \mathrm{H}\right]$ apomorphine binding over the concentration range of $10^{-9}$ to $10^{-4} \mathrm{M}$, but actually enhanced the specific binding of the agonist to the dopamine/neuroleptic binding (Fig. 3). A bellshaped dose-response curve was obtained for the influence of PLG on specific binding of $\left[{ }^{3} \mathrm{H}\right]$ apomorphine in the rat striatum, with the maximal effect occurring at approximately $10^{-6} \mathrm{M}$. In an attempt to further characterize the interaction of PLG with the dopamine/neuroleptic receptor, the specific binding of $\left[{ }^{3} \mathrm{H}\right]$ apomorphine was examined in the presence of $1 \mu \mathrm{M}$ of PLG and Scatchard analysis revealed the PLG selectively increased the apparent affinity of $\left[{ }^{3} \mathrm{H}\right]$ apomorphine binding sites by $50.9 \%$ as compared to the control in the absence of PLG (significantly different from the control, $p<0.05$ ) (Table 1). The $\mathrm{B}_{\max }$ of specific $\left[{ }^{3} \mathrm{H}\right]$ apomorphine binding was essentially unaltered. $\left[{ }^{3} \mathrm{H}\right]$ Spiroperidol, on the other hand, specifically bound to dopamine receptor sites with a single high-affinity component $\left(K_{D}=0.16 \pm 0.03 \mathrm{nM} ; B_{\max } 340 \pm 10.0\right.$ fmoles $\mathrm{mg}^{-1}$ protein). Drug competition studies revealed that haloperidol was the most potent in inhibiting specific $\left[{ }^{3} \mathrm{H}\right]$ spiroperidol binding $\left(\mathrm{IC}_{50}=6 \mathrm{nM}\right)$, followed by dopamine and ADTN, with their respective $\mathrm{IC}_{50}$ values of $4 \mu \mathrm{M}$ and $12 \mu \mathrm{M}$. PLG, on the other hand, did not exert any effect on the specific binding of $\left[{ }^{3} \mathrm{H}\right]$ spiroperidol over the concentration range of $0.01-100 \mu \mathrm{M}$.

Neuropeptides such as TRH and DALA were very weak in inhibiting specific $\left[{ }^{3} \mathrm{H}\right]$ spiroperidol and $\left[{ }^{3} \mathrm{H}\right]$ apomorphine binding with $\mathrm{IC}_{50}$ values $>100 \mu \mathrm{M}$.

\section{DISCUSSION}

The major findings of the present study indicate that (a) chronic, but not acute, administration of PLG antagonized haloperidol-induced catalepsy; (b) PLG selectively enhanced agonist binding to dopamine receptors in striatum at a concentration previously shown to be most effective in inhibiting dopamine-sensitive adenylate cyclase activity [21]. Our behavioural data confirmed an earlier study by Voith [35] on the antagonism of fluphenazine-induced catalepsy by PLG. It appears unlikely that the differential effect of acute versus chronic administration of the tripeptide may be explained simply on the basis of its relatively short pharmacological half-life [27] inasmuch as the duration of its anti-tremorlytic activity far exceeded its half-life disappearance from the plasma [26]. Our behavioural finding provides indirect evidence that PLG does not function as a prototypal agonist at the dopamine receptor. Conversely, protracted treatment with dopamine agonists like apomorphine have previously been demonstrated to potentiate, rather than antagonize, neuroleptic-induced catalepsy [23,29]; this behavioural manifestation of extrapyramidal motor dysfunction may be attributed to concomitant desensitization of the dopamine receptor [22]. Alternatively, the observed antagonism of haloperidol-induced catalepsy may be explicable in terms of its indirect facilitatory effect of PLG on nigro-striatal dopaminergic neurotransmission. However, different doses of haloperidol should be tested before definite conclusions can be drawn regarding the mode of interaction of PLG and haloperidol. Experiments along these lines are in progress.

Our biochemical studies on the effects of PLG on in vitro dopamine receptor binding in the striatum showed that PLG failed to inhibit competitively specific $\left[{ }^{3} \mathrm{H}\right]$ apomorphine and $\left[{ }^{3} \mathrm{H}\right]$ spiroperidol binding, but paradoxically enhanced the affinity of the dopamine receptor for agonists. Conceivably, this would be most beneficial in Parkinsonian disease, for the enhanced sensitivity of the dopamine receptor to the endogenously released dopamine and/or exogenously administered dopamine precursor, L-DOPA, may effectively compensate for the partially degenerating dopaminergic terminals in Parkinsonism. Furthermore, in a recent study of the action of PLG in the 6-hydroxydopamine-lesioned rotational model, PLG has been demonstrated to significantly potentiate the behavioural responses to apomorphine on denervation-induced supersensitive dopamine receptors [18].

The peculiar bell-shaped dose-response relationship describing the facilitatory effect of PLG on $\left[{ }^{3} \mathrm{H}\right]$ apomorphine binding in vitro (Fig. 3) merits some comment. In animal studies in vitro, Bjorkman and Sievertsson [4] found similar anomalous dose-effect phenomenon in the 


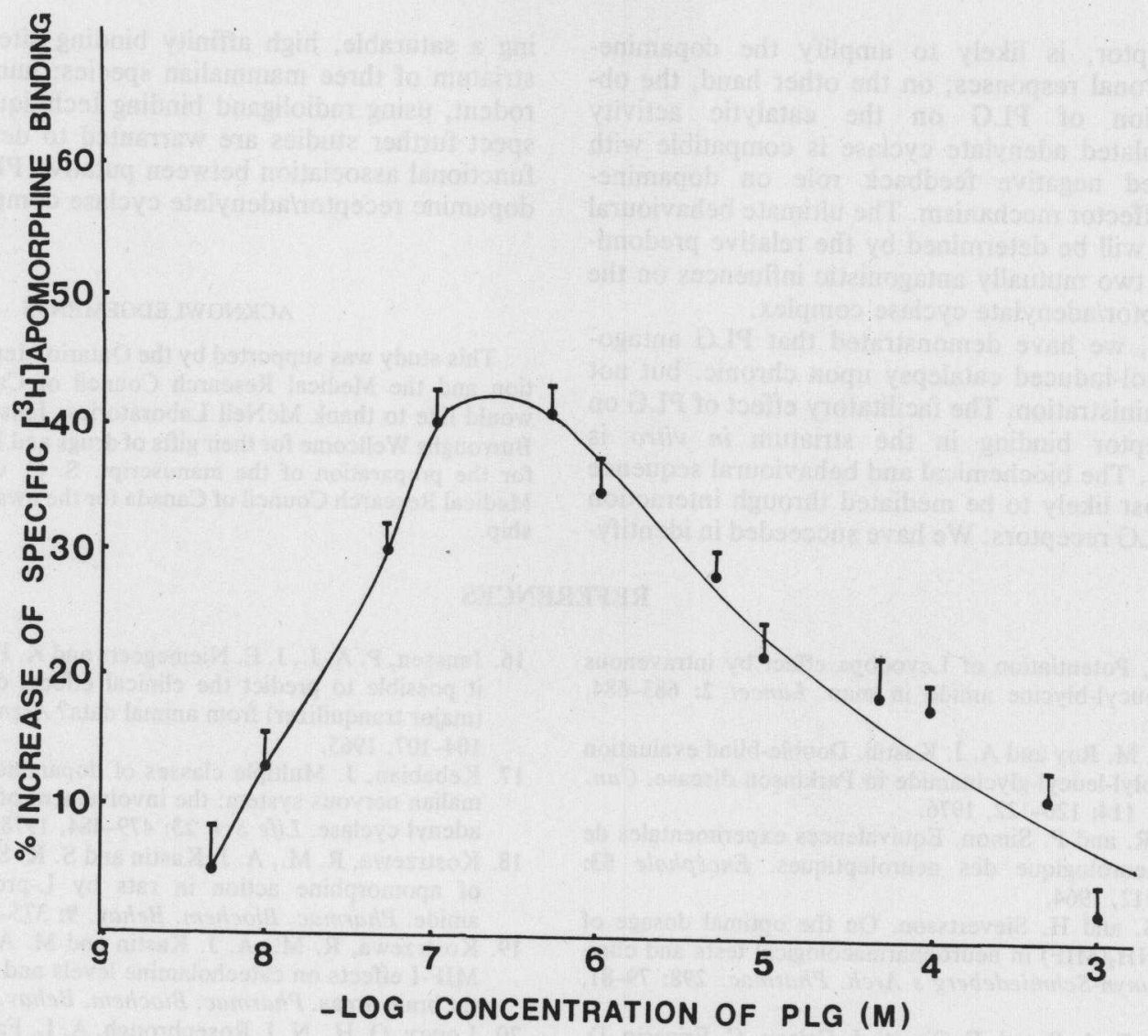

FIG. 3. Dose-response relationship of the influence of PLG on specific $\left[{ }^{3} \mathrm{H}\right]$ apomorphine binding in the striatum in vitro. Various concentrations of PLG were added to the incubation mixture and specific $\left[{ }^{3} \mathrm{H}\right]$ apomorphine binding was defined as the difference in binding occurring in the presence and absence of $10 \mu \mathrm{M}$ of unlabelled apomorphine. No PLG was included in the control and the final concentration of $\left[{ }^{3} \mathrm{H}\right]$ apomorphine was $3 \mathrm{nM}$. The values represent the mean $\pm \mathrm{SEM}$ from four independent experiments performed in triplicate, with the SEM less than $10 \%$ of the mean.

paradigm of antagonism of oxotremorine-induced tremor. These behavioural findings may be interpreted as differential interaction of PLG with heterogeneous populations of highand low-affinity receptor binding sites for the neuroregulatory peptide. Recognition of this unique dose-response relationship may have some implications in designing therapeutic strategy of PLG: the therapeutic response of PLG in Parkinsonian and depressive patients has been shown to decline with higher doses $[2,12]$. Moreover, the pharmacological action of PLG appears to depend on the sensitivity of the dopamine receptors, as evidenced by the failure of PLG to elicit favourable therapeutic outcomes from Parkinsonian patients maintained on chronic L-DOPA therapy which possibly causes refractoriness of the post-synaptic dopamine receptors [5].

The interaction of PLG with the dopamine receptors exhibits specificity for the agonists, since it did not affect the specific binding of the antagonist $\left[{ }^{3} \mathrm{H}\right]$ spiroperidol binding to the receptor. In this respect the modulatory effect of PLG on the affinity of the dopamine receptor for agonists and the sensitivity of the cyclase system to dopamine stimulation is dence derived from lesion and drug specificity studies suggests that $\left[{ }^{3} \mathrm{H}\right]$ apomorphine and $\left[{ }^{3} \mathrm{H}\right]$ spiroperidol label different neuronal elements $[1,3,17]$, though they may both be associated with dopamine sensitive adenylate cyclase. Furthermore, the property of PLG in enhancing specific dopamine agonist binding is not shared by other neuropeptides such as TRH and enkephalins. It remains to be seen whether in vivo administration of PLG will alter the affinity of the dopamine receptor, and restore the sensitivity of the receptor when the latter has been desensitized or hypersensitized by pharmacological or surgical manipulations.

It appears difficult to reconcile the in vitro effect of PLG on striatal dopamine receptor binding with the failure of acute administration of PLG to antagonize the behavioural manifestations of dopamine receptor blockade in vivo, as observed in our present study. Post-receptor synaptic events may also mediate the behavioural manifestations of dopamine receptor blockade in vivo, as observed in our present study. Post-receptor synaptic events may also mediate the behavioural effects of neuroleptics and PLG has previously been shown to inhibit dopamine-sensitive adeny- 
dopamine receptor, is likely to amplify the dopaminedependent neuronal responses; on the other hand, the observed inhibition of PLG on the catalytic activity dopamine-stimulated adenylate cyclase is compatible with its hypothesized negative feedback role on dopaminespecific neuroeffector mechanism. The ultimate behavioural profile of PLG will be determined by the relative predominance of these two mutually antagonistic influences on the dopamine receptor/adenylate cyclase complex.

In summary, we have demonstrated that PLG antagonized haloperidol-induced catalepsy upon chronic, but not upon acute administration. The facilitatory effect of PLG on dopamine receptor binding in the striatum in vitro is agonist-specific. The biochemical and behavioural sequence of events is most likely to be mediated through interaction with specific PLG receptors. We have succeeded in identify- ing a saturable, high affinity binding site for PLG in the striatum of three mammalian species: human, bovine, and rodent, using radioligand binding technique [7]. In this respect further studies are warranted to define the mode of functional association between putative PLG receptors and dopamine receptor/adenylate cyclase complex.

\section{ACKNOWLEDGEMENTS}

This study was supported by the Ontario Mental Health Foundation and the Medical Research Council of Canada. The authors would like to thank McNeil Laboratories, Janssen Pharmaceutica, Burroughs Wellcome for their gifts of drugs and Miss Jennifer Birrell for the preparation of the manuscript. S. C. would like to thank Medical Research Council of Canada for the award of MRC studentship.

\section{REFERENCES}

1. Barbeau, A., Potentiation of Levodopa effect by intravenous L-prolyl-L-leucyl-blycine amide in man. Lancet 2: 683-684, 1975.

2. Barbeau, A., M. Roy and A. J. Kastin. Double-blind evaluation of oral L-prolyl-leucyl-glycinamide in Parkinson disease. Can. Med. Ass. J. 114: 120-122, 1976.

3. Boissier, J. R. and P. Simon. Equivalences experimentales de syndrome neurologique des neuroleptiques. Encéphale 53: Suppl. 109-112, 1964.

4. Bjorkman, S. and H. Sievertsson. On the optimal dosage of pro-leu-gly- $\mathrm{NH}_{2}$ (MIF) in neuropharmacological tests and clinical use. Naunyn-Schmiedeberg's Arch. Pharmac. 298: 79-81, 1977.

5. Caraceni, T., E. A. Parati, F. Girotti, I. Celano, C. Frigerio, D. Cooch and E. E. Muller. Failure of MIF-I to affect behavioural responses in patients with Parkinson's disease under L-DOPA therapy. Psychopharmacology 63: 217-222, 1979.

6. Chiu, S. and R. K. Mishra. Antagonism of morphine-induced catalepsy by L-prolyl-L-leucyl-glycinamide. Eur. J. Pharmac. 53: 119-125, 1979.

7. Chiu, S. and Y. W. Wong and R. K. Mishra. Direct evidence for L-prolyl-leucyl-glycinamide (PLG) receptor in mammalian brain. Fedn Proc. 64: 625, 1980 (Abstract).

8. Christenssen, C. W., C. T. Harston, A. J. Kastin, R. M. Kostrzewa and M. A. Spirtes. Investigations on MSH and MIF-I effects on cyclic AMP levels in rat brain. Pharmac. Biochem. Behav. 5: Suppl. 1, 117-120, 1976.

9. Creese, I., T. Prosser and S. H. Snyder. Dopamine receptor binding: specificity; localization and regulation by ions and guanyl nucleotides. Life Sci. 23: 495-500, 1978.

10. Creese, I., T. B. Usdin and S. H. Snyder. Dopamine receptor binding regulated by guanine nucleotides. Molec. Pharmac. 16: 68-76, 1979.

11. Czlonkowski, A., V. Hollt and A. Herz. Binding of opiates and endogenous opioid peptides to neuroleptic receptor sites in the corpus striatum. Life Sci. 22: 953-962, 1978.

12. Ehrensing, R. H. and A. J. Kastin. Dose-related biphasic effect of prolyl-leucyl-glycinamide (MIF-I) in depression. Am. J. Psychiat. 135: 562-566, 1978.

13. Fischer, P. A., E. Schneider, P. Jacobi and H. Maxion. Effect of Melanocyte-Stimulating Hormone-Release Inhibiting Factor (MIF) in Parkinsonian Syndrome. Eur. Neurol. 12: 360-368, 1974.

14. Friedman, E., J. Friedman and S. Gershon. Dopamine synthesis: stimulation by a hypothalamic factor. Science 182: 831-832, 1973.

15. Huidobro-Toro, J. P., A. Scotti de Carolis and V. G. Longo. Actions of two hypothalamic factors (TRH, MIF) and of angiotensin II on behavioural effects of L-DOPA and 5-hydroxytryptophan in mice. Pharmac. Biochem. Behav. 2:
16. Janssen, P. A. J., J. E. Niemegeers and K. H. L. Schellekens. Is it possible to predict the clinical effects of neuroleptic drugs (major tranquilizer) from animal data? Arzneimittel-Forsch. 15: 104-107, 1965.

17. Kebabian, J. Multiple classes of dopamine receptors in mammalian nervous system: the involvement of dopamine-sensitive adenyl cyclase. Life Sci. 23: 479-484, 1978.

18. Kostrzewa, R. M., A. J. Kastin and S. K. Sobrian. Potentiation of apomorphine action in rats by L-prolyl-L-leucyl-glycine amide. Pharmac. Biochem. Behav. 9: 375-378, 1978.

19. Kostrzewa, R. M., A. J. Kastin and M. A. Spirtes. MSH and MIF-I effects on catecholamine levels and synthesis in vari : rat brain areas. Pharmac. Biochem. Behav. 3: 1017-1023, 1

20. Lowry, O. H., N. J. Rosenbrough, A. L. Farr and R. J. Rai. Protein measurement with the Folin phenol reagent. J. bic Chem. 139: 265-275, 1951.

21. Mishra, R. K. and M. H. Makman. Interaction of prolyl-leucyl-glycinamide a hypothalamic factor, with adenylatı cyclase associated with dopamine in rat striatum and monkey striatum and retina. Pharmacologist 17: 115, 1975 (Abstract).

22. Mishra, R. K., Y. W. Wong, S. L. Varmuza and L. Tuff. Chemical lesions and drug-induced supersensitivity of caudate dopamine receptors. Life Sci. 23: 443-446, 1978.

23. Muller, S. and P. Seeman. Presynaptic subsensitivity as a possible basis for sensitization by long-term dopamine mimetics. Eur. J. Pharmac. 55: 149-158, 1979.

24. Nair, R. M. G., A. J. Kastin and A. V. Schally. Isolation and structure of hypothalamic MSH-release-inhibiting hormone. Biochem. biophys. Res. Commun. 43: 1376-1381, 1971.

25. Plotnikoff, N. P. and A. J. Kastin. Pharmacological studies with a tripeptide L-prolyl-L-leucyl-glycinamide. Archs int. Pharmacodyn. Ther. 211: 211-224, 1974.

26. Plotnikoff, N. P. and A. J. Kastin. Oxotremorine antagonism by prolyl-leucyl-glycine amide administered by different routes and with several anticholinergics. Pharmac. Biochem. Behav. 2: 417-419, 1974.

27. Redding, T. W., A. J. Kastin, R. M. G. Nair and A. V. Schally. The distribution half-life and excretion of $\left[{ }^{14} \mathrm{C}\right]$ and $\left[{ }^{3} \mathrm{H}\right]$ labelled L-prolyl-L-leucyl-glycinamide in the rat. Neuroendocrinology 11: $92-100,1973$.

28. Schally, A. V., D. H. Coy and C. A. Meyers. Hypothalamic regulatory hormones. A. Rev. Biochem. 47: 89-128, 1978.

29. Scatton, B. and P. Worms. Subsensitivity of striatal and mesolimbic dopamine target cells after repeated treatment with apomorphine dipivaloyl ester. Naunyn-Schmiedeberg's Arch. Pharmac. 303: 271-278, 1979.

30. Schulz, J., G. L. Kovacs and G. Telegdy. Action of posterior pituitary neuropeptides on the nigrostriatal dopaminergic system. Eur. J. Pharmac. 57: 185-190, 1979. 
31. Schwarz, R., I. Creese, J. T. Coyle and S. H. Snyder. Dopamine receptors localized on cerebral cortical afferents to rat corpus striatum. Nature 271: 766-768, 1978.

32. Smith, J. and M. Morgan. Effects of L-prolyl-L-leucyl-glycine amide (MIF) on rotational behaviour in substantia nigrallesioned rats. Pharmacologist 21: 502, 1979 (Abstract).

33. Walter, R., R. G. Ritzman, H. N. Bhargava and L. B. Flexner. Prolyl-leucyl-glycinamide, cycl(leucylglycine), and derivatives block development of physical dependence on morphine in mice. Proc. natn. Acad. Sci. U.S.A. 76: 518-520, 1979.
34. Versteeg, D. H. G., M. Tanaka, E. R. Dekloat, J. M. VanRee and D. DeWied. Prolyl-leucyl-glycinamide (PLG): regional effects on a-MPT-induced catecholamine disappearance in rat brain. Brain Res. 143: 561-566, 1978.

35. Voith, K. Synthetic MIF analogues. Arzneimittel-Forsch. 27: 2290-2293, 1977. 